\title{
EKSISTENSI MODAL SOSIAL DALAM PENGELOLAAN EKOWISATA BEKANTAN OLEH POKDARWIS LESTARI SUNGAI HITAM TERHADAP UPAYA MENGHADAPI DAMPAK COVID-19 DI SAMBOJA
}

\author{
Karina Pramesti Utami, Luluk Murni Wahyuni, Ranu Wijaya \\ Pertamina Hulu Mahakam \\ Email: karina.pramesti.u@mail.ugm.ac.id
}

\begin{abstract}
Ecotourism Bekantan in Samboja has become a well-known tourist spot because in bekantan ecotourism tourists are invited to go along the river to see the bekantan. Research on bekantan ecotourism as a means of tourism and education has been conducted in Kampung Lama Village, Samboja District, East Kalimantan. The aim is to get information on how the bekantan population is in its natural habitat by seeing whether the food is sufficient and seeing where it lives so that the bekantan feel safe and comfortable. The black river is one of the areas inhabited by endemic animals of Kalimantan, namely the bekantan. Currently, the bekantan habitat has become a tourist spot and a means of education for people from within the region as well as outside the region and even abroad. In a pandemic like now, the covid-19 virus has caused many parties to experience its effects, especially for bekantan ecotourism and its management, namely Pokdarwis Lestari Sungai Hitam. With this research, it is hoped that we can find out how things are in the black river after the covid-19 virus. The method used is a qualitative research method in which it is explained by means of descriptions. With the Covid-19 pandemic, ecotourism activities on the Black River have become quiet tourists. The management of Pokdarwis Lestari in Sungai Hitam no longer gets tourists, so many of them are unemployed. Therefore, PT Pertamina Hulu Mahakam held eucalyptus oil refining training to help the managers of Pokdarwis Lestari Sungai Hitam get income by utilizing eucalyptus oil trees around the Sungai Hitam area. For this ecotourism development activity in Sungai Hitam, it is hoped that there will be an increase in public awareness to manage and utilize eucalyptus oil trees which are used as bekantan beds and can also be processed as white oil extract which can get a sale value so that it is not cut down by the surrounding community. With this eucalyptus oil refining training, it is hoped that it can produce eucalyptus oil products that are unique to the black river ecotourism as a souvenir of tourists and also as additional income for members of Pokdarwis Lestari Sungai Hitam.
\end{abstract}

Keywords: Bekantan Habitat, Ecotourism, Eucalyptus Oil

\begin{abstract}
Abstrak
Sungai hitam merupakan salah satu daerah yang dihuni oleh satwa endemik Kalimantan yaitu bekantan. Saat ini, habitat bekantan telah menjadi tempat wisata dan sarana edukasi bagi masyarakat baik dari dalam daerah maupun luar daerah bahkan mancanegara. Ekowisata yang ada di Sungai Hitam ini dinamakan sebagai Sungai Hitam Lestari dengan pengelolanya adalah Pokdarwis yang ada di Kelurahan Kampung Lama. Sungai Htam Lestari ini menyajikan wisata yang dibalut dengan edukasi mengenai kehidupan bekantan dengan berkeliling menyusuri sungai menggunakan perahu. Dalam pandemi seperti sekarang, virus covid-19 telah menyebabkan banyak pihak merasakan dampaknya, terutama bagi ekowisata bekantan dan pengelolaannya yaitu Pokdarwis Lestari Sungai Hitam. Dengan adanya penelitian ini diharapkan dapat diketahui bagaimana keadaan di sungai hitam pasca virus covid-19. Dengan adanya lahan hibah dari masyarakat untuk menjadi tempat tinggal bekantan dan juga sebagai lahan yang ditanami tumbuhan pohon minyak kayu putih yang mana minyak kayu putih ini sebagai upaya untuk mencegah dari virus covid-19. Metode yang digunakan adalah metode penelitian kualitatif yang dijelaskan melalui deskripsi. Dengan pandemi Covid-19, aktivitas ekowisata di Sungai Hitam menjadi sepi wisatawan. Pengurus Pokdarwis Lestari di Sungai Hitam tidak lagi mendatangkan wisatawan sehingga banyak yang menganggur. Oleh karena itu, PT Pertamina Hulu Mahakam mengadakan pelatihan pemurnian minyak kayu putih untuk membantu pengelola Pokdarwis Lestari Sungai Hitam mendapatkan penghasilan dengan memanfaatkan pohon minyak kayu putih di sekitar kawasan Sungai Hitam. Untuk kegiatan pengembangan ekowisata di Sungai Hitam ini diharapkan ada peningkatan kesadaran masyarakat untuk mengelola dan memanfaatkan pohon minyak kayu putih yang dijadikan bedengan bekantan dan juga dapat diolah sebagai ekstrak minyak putih yang dapat memperoleh nilai jual sehingga agar tidak ditebang oleh masyarakat sekitar. Dengan adanya pelatihan pemurnian minyak kayu putih ini diharapkan dapat menghasilkan produk minyak kayu putih yang khas dari ekowisata sungai hitam sebagai oleh-oleh wisatawan dan juga sebagai tambahan penghasilan bagi anggota Pokdarwis Lestari Sungai Hitam.
\end{abstract}

Kata Kunci: Habitat Bekantan, Ekowisata, Minyak Kayu Putih 


\section{Pendahuluan}

Bekantan yang mempunyai nama latin (Nasalis larvatus Wurmb) merupakan satwa endemik yang mendiami daerah Kalimantan Timur khususnya yang ada di Sungai Hitam Kelurahan Kampung Lama, Kecamatan Samboja, Kabupaten Kutai Kertanegara, Kalimantan Timur. Bekantan ini hidup secara berkelompok dan ketika berpindahpun akan tetap berkelompok dengan kelompoknya. Satwa ini hidup di hutan mangrove atau daerah sungai yang mempunyai stok makanan dan tempat tinggal yang nyaman bagi mereka. Hutan mangrove yang ada di sungai hitam menjadi salah satu tempat yang ada satwa endemiknya. Mereka mencari makan dari mangrove yang ada di sekitar tempat tinggal mereka. Jika makanannya habis, banyak dari mereka mencari makanan keluar hutan seperti ke pemukiman warga. Namun hal ini sekarang jarang terjadi karena makanan mereka sudah banyak ditanam di dalam daerah sungai hitam. Daerah hutan mangrove ini dekat dengan permukiman warga yang banyak menghibahkan lahannya untuk tempat tinggal bekantan di sungai hitam.

Masyarakat dan pengelola
POKDARWIS Lestari Sungai Hitam
mendapatkan banyak apresiasi seiring dengan semakin banyaknya populasi Bekantan yang dirawat secara sukarela. Apresiasi tersebut berupa dukungan dari pemerintahan dari kelurahan, kecamatan sampai pembinaan kabupaten sangat berpengaruh bagi ekowisata bekantan ini. Selain itu juga ekowisata ini mendapatkan penghargaan seperti KALPATARU dari Bupati Kutai Kartanagara. Banyak sekali dukungan yang di dapatkan oleh ekowisata bekantan ini tidak hanya dari PT Pertamina Hulu Mahakam saja akan tetapi ada juga dukungan dari perusahaan lain seperti Pertamina EP serta ENI Muara Bakau.
Sei Hitam juga menjadi tempat wisata dan edukasi bagi masyarakat yang berada di dalam negeri maupun dari luar negeri. Kedatangan wisatawan ke daerah wisata khususnya di Sei Hitam akan membuka peluang kerja bagi masyarakat sekitar. Banyak masyarakat yang datang hanya untuk melihat bekantan saja dan ada juga yang menjadikan sebagai sarana edukasi untuk mengetahui bagaimana kehidupan bekantan. Dengan adanya tempat ekowisata bekantan ini memberikan manfaat bagi masyarakat yaitu memberdayakan masyarakat sekitar untuk ikut mengelola dan menjaga ekowisata. Di masa covid-19 sekarang ini tempat wisata bekantan ini ditutup demi menjaga keamanan dan kenyamanan bekantan dan membantu pemerintah untuk memutus rantai virus yang ada.

Banyak sekali yang terdampak dari adanya virus covid-19 ini salah satunya ialah para pengelola wisata edukasi bekantan atau yang sering disebut dengan Pokdarwis Sungai Hitam. Anggota pokdarwis yang menggantungkan hidupnya dengan tempat wisata ini sekarang hanya di rumah dan harus tetap memenuhi kebutuhan keluarganya. Maka dari itu, perusahaan menyediakan sebuah pelatihan penyulingan minyak kayu putih di sei hitam. Latar belakang dilakukannya pelatihan ini ialah banyak sekali pohon minyak kayu putih yang ada di ekowisata dimana tanah tersebut merupakan tanah hibah dari salah satu warga masyarakat di Samboja yang merupakan salah satu modal sosial bagi ekowisata bekantan. $\mathrm{Di}$ dalam tempat konservasi bekantan yang mana pohon minyak kayu putih ini biasanya ditebangi oleh masyarakat sekitar untuk kayu bakar atau pagar rumah masyarakat. Hal ini dilakukan agar masyarakat khususnya anggota pokdarwis memperoleh pengetahuan bagaimana cara mengolah pohon minyak kayu untuk 
mendapatkan nilai jual dan juga sebagai pemasukan anggota pokdarwis di masa virus covid-19 seperti sekarang ini.

Berdasarkan latar belakang masalah maka dirumuskan masalah penelitian sebagai berikut : bagaimana proses kontribusi modal sosial dalam kelompok pokdarwis bekantan sungai hitam dengan adanya pandemik covid19 serta bagaimana peran masyarakat dalam memberdayakan bekantan saat pandemik di Kelurahan Kampung Lama, Kecamatan Samboja, Kalimantan Timur?

\section{Metode Penelitian}

Pada bab ini akan dijelaskan tentang bagaimana penelitian akan dilaksanakan secara operasional. Oleh karena itu, pada bagian ini akan diuraikan hal-hal seperti jenis penelitian, lokasi penelitian, teknik penentuan informasn, teknik pengumpulan data, validitas data serta teknik analisis data. Penelitian ini dilakukan pada bulan Juni 2020. Metode penelitian yang digunakan dalam penelitian ini adalah metode penelitian kualitatif. Penelitian kualitatif merupakan jenis penelitian yang menggunakan latar alamiah dengan maksud menafsirkan fenomena yang terjadi dan dilakukan dengan jalan melibatkan berbagai metode yang ada (Denzin \& Lincoln 1994). Data dalam penelitian kualitatif berisi data deskriptif yang umumnya berbentuk kata-kata, gambar-gambar, atau rekaman.

Penelitian kualitatif ini membantu pembaca berdasarkan latar belakang peneliti dalam mencari informasi yang lebih menekankan menggunakan metode kualitatif dengan pendekatan deskriptif. Sementara itu untuk menggali data secara mendalam penelitian kualitatif ini menggunakan pendekatan fenomenologis yang sering sekali digunakan dalam bentuk penelitian sosial. Penelitian sosial yang menggunakan pendekatan ini memiliki tujuan untuk menggambarkan sebuah kondisi, situasi, ataupun fenomena sosial dalam masyarakat yang menjadi objek penelitian serta menyimpulkan realitas sebagai suatu ciri, karakter atau model dari fenomena yang dideskripsikan. Sedangkan lokasi penelitian ini berfokus dengan kontribusi modal sosial yang ada dengan dampak covid-19 bagi habitat satwa endemik yaitu bekantan serta peran masyarakat yang ada di Sungai Hitam, Kecamatan Samboja, Kabupaten Kutai Kartanegara, Kalimantan Timur.

Pada penelitian kualitatif, ada beberapa tahap dalam proses penyelesaian penelitian yaitu diawali dengan pengumpulan data, reduksi data dan penyajian data yang digambarkan menggunakan kata-kata, tabel,grafik sesuai dengan kebutuhan penelitian. Maka dari itu, peneliti harus memiliki kemampuan berinteraksi dan komunikasi yang baik agar mendapatkan informasi yang akurat dan mendalam dari informan. Sama halnya dengan penelitian ini, penggunaan jenis penelitian deskriptif kualitatif yaitu medeskripsikan bagaimana dengan dampak covid-19 bagi habitat satwa endemik yaitu bekantan serta peran masyarakat yang ada di Sungai Hitam, Kecamatan Samboja, Kabupaten Kutai Kartanegara, Kalimantan Timur.

Sumber Data merupakan bagian yang sangat penting bagi peneliti karena ketepatan memilih dan menentukkan jenis sumber data akan menentukkan ketepatan serta memperkaya data atau informasi yang diperoleh. (Sutopo H. B., 2002). Sumber data primer adalah data utama yang digunakan dalam penelitian, sedangkan sumber data sekunder digunakan sebagai pendukung data primer. Sumber data primer yang digunakan dalam penelitian ini adalah wawancara, sedangkan data sekunder yang digunakan 
adalah observasi, dokumentasi, dan dokumen atau arsip.

\section{Temuan Penelitian}

Penelitian dengan tema ini sudah banyak dilakukan oleh beberapa peneliti sebelumnya. Dalam proses penyusunan penelitian ini saya menggunakan studi literature untuk digunakan sebagai bahan pembuktian bahwa penelitian yang disusun berbeda dengan penelitian sebelumnya, yaitu :

a. Penelitian mengenai ekowisata bekantan oleh Tri Atmoko dengan judul "Strategi Pengembangan Ekowisata Pada habitat bekantan (Nasalis larvatus Wurmb.) Di kuala Samboja, Kalimantan Timur" yang ditulis oleh Balai Penelitian Teknologi Perbenihan Samboja, tahun 2010. Penelitian ini menggunakan metode observasi secara langsung dan mendeskripsikan secara langsung. Hasil penelitian ini adalah Sungai Kuala Samboja memiliki arti penting bagi habitat tempat tinggal bekantan dan masyarakat sekitar yaitu sebagai fungsi hidroorlogis, ekologis, dan berbagai tempat berekembangbiak berbagai jenis ikan komersial serta sebagai indikator banjir.

b. Penelitian mengenai wisata yang berkaitan dengan bekantan oleh Yudhi Putrayanda dengan judul jurnal "Melestarikan Bekantan: Wisata Berbasis Kearifan Lokal Di Desa Sungai Rutas, Kabupaten Tapin" yang ditulis oleh Badan Penelitian dan Pengembangan Daerah Provinsi Kalimantan Selatan. Penelitian ini menggunakan metode kualitatif dengan analisis deskriptif. Hasil dari penelitian ini mengatakan bahwa masih minimnya infrastruktur di Desa Sungai Rutas,
Kabupaten Tapin sehingga keberadaan pelabuhan datu muning terkesan sangat minim dan wisatawan tidak mengetahui bahwa dilokasi tersebut terdapat pelabuhan yang menjadi starting point wisata susur Sungai Rutas. Tujuan utama dari pariwisata ini pada awalnya adalah wisata religi yang digabungkan dengan konsep wisata alam menyusuri Sungai Rutas dengan suguhan keberadaan bekantan yang menjadi daya tarik di pariwisata Sungai Rutas.

c. Penelitian mengenai peranan modal sosial oleh Yudianto dengan judul skripsi "Peranan Modal Sosial Dalam Pengembangan Kelompok Usaha Kecil (Studi Mengenai Kelompok Batik Tulis Kebon Indah di Desa Kebon, Kecamatan Bayat, Kabupaten Klaten)" yang ditulis oleh mahasiswa Program Studi Pembangunan Sosial dan Kesejahteraan, Fakultas IImu Sosial dan IImu Politik, tahun 2017. Penelitian ini menggunakan metode kualitatif. Hasil dari penelitian ini adalah peranan modal sosial yang semula hanya menjadi perekat kehidupan masyarakat, namun seiring terbentuknya kelompok batik tulis kebon indah maka modal sosial tersebut menjadi kunci bagi masyarakat untuk meningkatkan taraf hidupnya guna mencapai kehidupan yang lebih tertata dan sejahtera melalui usaha bersama.

Berbeda dengan ketiga penelitian di atas, penelitian ini lebih melihat ekowisata bekantan yang ada di Sungai Hitam, Kelurahan Samboja di masa sekarang ini yang ikut terdampak dari adanya virus covid-19. Hasil temuan dari penelitian ini ialah melihat bagimana pengelola 
Pokdarwis Lestari Sungai Hitam pada saat pandemik covid-19. Penelitian ini melihat pada segi proses modal sosial memiliki manfaat dimana masyarakat ikut terlibat di dalamnya baik sebagai obyek (penerima manfaat) maupun subyek (pelaku/aktor). Penelitian yang dilakukan peneliti berupa penelitian kualitatif.

\section{Pembahasan}

\section{Kondisi Alam Sungai Hitam}

Habitat bekantan yang ada Samboja ini sebagian besar tanaman yang ada didalamnya ialah pohon kayu putih dan mangrove. Ancaman bekantan yang ada di Samboja ini terjadi sekitar 20 tahun yang lalu dimana tempat tinggal bekantan ini terisolasi di antara sejumlah penggunaan lahan di sekitar Daerah Aliran Sungai (DAS). Pada tahun 1999-2000 lahan mangrove di sempadan sungai mengalami degradasi yang mengakibatkan hutan mangrove dialih fungsikan menjadi tambak. Tidak lama setelah itu tambak yang ada pernah di kelola oleh masyarakat terbengkalai karena produksinya sudah mulai menurun. Setelah itu lahan tambak yang sudah tidak terawat dipulihkan dengan cara merehabilitasi lahan tersebut. Pada tahun 2019 Pertamina Hulu Mahakam ini melakukan rehabilitasi dengan menanam lebih dari 5000 pohon penyanggah di sekitar hutan mangrove dengan tujuan agar bisa mempertahankan fungsi hutan mangrove sebagai habitat bekantan dan membantu agar populasi bekantan tidak semakin punah.

Hutan mangrove yang ada di Sungai Hitam Kecamatan Samboja merupakan salah satu kecamatan yang masuk didalam wilayah binaan dengan kategori ring 2 PT Pertamina Hulu Mahakam. Di dalam kawasan hutan mangrove ini selain untuk tempat tinggal bekantan juga dilakukan sebagai tempat wisata. Tempat wisata edukasi bagi masyarakat dalam dan luar negeri. Untuk bagian pengelolaan kawasan wisata bekantan ini mempunyai kelompok yang dianamakan Pokdarwis Lestari. Pokdarwis ini bertugas untuk membantu membersihkan dan mengelola kawasan hutan wisata juga sebagai tour guide atau pemandu wisata bagi wisatawan yang berkunjung ke Sungai Hitam.

Tumbuhan minyak kayu puth yang mempunyai nama latin Melaleuca leucadendra yang termasuk dalam family Myrtaceae merupakan pohon anggota suku jambujambuan yang dimanfaatkan sebagai sumber minyak kayu puth. Minyak yang diekstrak diambil dari daun dan rantingnya. Pohon minyak kayu putih ini banyak sekali ditemukan di dalam kawasan wisata bekantan Sungai Hitam. Biasanya pohon minyak kayu putih ini ditebang oleh masyarakat sekitar untuk dibuat bangunan rumah meskipun kualitas kayu nya tidak terlalu kuat. Selain itu po hon minyak kayu puth ini digunakan sebagai tempat tidur dan juga tempat bermain bekantan serta bisa juga menjadi alternative makanan bagi bekantan selain mangrove.

a. Pandemi covid-19 di Sungai Hitam

Pandemi merupakan suatu wabah penyakit global. World Health Organization (WHO) mengatakan bahwa kategori pandemi dinyatakan ketika penyakit baru menyebar di seluruh dunia melampaui batas. Dengan adanya pandemic covid-19 ini banyak sekali yang terkena dampaknya. Salah satunya adalah pergerakan kehidupan ekowisata yang ada di Sungai Hitam. Ada banyak sekali batasan yang harus dilakukan. Tidak boleh berkumpul dalam satu area tertentu, harus jaga jarak antar manusia serta harus memperhatikan kesehatan dan kebersihan dengan melakukan sering cuci tangan dan tidak boleh kontak langsung dengan manusia. Kegiatan berkumpul yang sering dilakukan oleh masyarakat untuk bersosialisasi harus dibatasi dan kalau terpaksa harus berkumpul harus memperhatikan jarak antar 
masyarakat. Istilah social distancing sekarang kerap kali diucapkan oleh masyarakat. Arti dari social distancing ialah salah satu strategi yang digunakan di ranah kesehatan untuk memperlambat penyebaran virus. Hal ini dimaksudkan agar manusia bisa tetap bergaul dan bersosialisasi akan tetapi harus memperhatikan jarak satu sama lain, jarak minimal adalah 6 kaki atau 1,8 meter.

\section{b. Dampak Covid-19}

Di masa pandemic covid-19 seperti sekarang ini banyak sekali tempat wisata yang terdampak, seperti halnya di wisata bekantan Sungai Hitam. Banyak masyarakat yang menggantungkan hidupnya di tempat wisata tersebut. Anggota Pokdarwis Lestari Sungai Hitam merasa tidak ada pemasukan sama sekali saat lockdown karena covid-19 sampai sudah new normal seperti sekarang ini. Oleh karena itu PT Pertamina Hulu Mahakam ikut membantu masyarakat dengan memberikan bantuan serta yang tidak kalah penting yaitu memberikan pelatihan penyulingan minyak kayu putih secara online. Hal ini dilakukan agar masyarakat tidak menebang pohon minyak kayu putih yang ada disana dan juga sebagai bekal pengetahuan bagi masyarakat untuk bisa mengolah daun minyak kayu puth menjadi barang yang yang mempunyai nilai ekonomi lebih tinggi.

Selain membantu memberikan pelatihan penyulingan minyak kayu putih secara online PT Pertamina Hulu Mahakam juga membuatkan tempat cuci tangan di tempat wisata bekantan Sungai Hitam sebagai bentuk kesiapsiagaan bencana covid-19 dengan tujuan masyarakat yang ada di area wisata bekantan Sungai Hitam ini bisa menjaga kebersihan agar meminimalisir penyebaran covid-19.

\section{Konsep Modal Sosial}

Menurut Woolcock (1998) konsep modal sosial adalah suatu mekanisme dan hubungan antara kepercayaan, norma, dan jaringan dalam pengaturan sosial di suatu daerah. Dengan menggunakan modal sosial ini dapat menjadi modal kuat yang dibangun oleh masyarakat setempat dan juga organisasi-organisasi yang ada. Dengan adanya pandemi covid-19 ini daerah yang tidak mempunyai riwayat bencana atau bukan merupakan kawasan rawan bencana biasanya kurang memulai adaptasi mitigasi structural sederhana hingga pertahanan structural yang kompleks karena belum siap dengan adanya virus ini dan siap tidak siap harus menghadapinya hingga waktu yang tidak ditentukan. Untuk menjaga modal sosial yang bersumber dari masyarakat lokal sendiri perlu adanya penilaian persepsi masyarakat sebagai solusi untuk mengatasi masalah-masalah lingkungan.

Modal sosial seringkali dikaitkan dengan upaya mengelola, meningkatkan dan mendayagunakan relasi-relasi sosial sebagai sumber daya yang diinvestasikan untuk memperoleh keuntungan ekonomi atau manfaat sosial. Ada tiga parameter modal sosial, yaitu :

a. Kepercayaan

Kepercayaan merupakan harapan yang tumbuh di dalam sebuah masyarakat yang ditunjukkan dengan perilaku jujur,teratur serta kerjasama berdasarkan dengan norma-norma yang dianut bersama. Kaitannya dengan Pokdarwis Lestari Sungai Hitam dan masyarakat sekitar yang sudah percaya dalam melindungi dan melestarikan habitat bekantan serta sebagian masyarakat yang memberikan lahannya untuk di hibahkan sebagai habitat bekantan.

b. Norma

Menurut Putnam norma terdiri dari berbagai pemahaman, nilai-nilai, harapan-harapan dan juga tujuan-tujuan yang diyakini dan dijalankan bersama oleh sekelompok orang. Norma tersebut bersumber dari agama, 
panduan moral, serta standar-standar sekuler seperti halnya kode etik professional. Dalam kaitannya dengan habitat bekantan di Sungai Hitam, masyarakat sekitar masih mempertahankan habitat asli bekantan dan membiarkan bekantan hidup berdampingan dengan masyarakat.

c. Jaringan

Merupakan infrastruktur dinamis dari modal sosial berwujud jaringan-jaringan kerjasama antar masyarakat. Kaitannya dengan penelitian ini ialah saat pandemi covid-19 seperti sekarang ini Pokdarwis Lestari Sungai Hitam yang merupakaan daerah binaan dari PT Pertamina Hulu Mahakam bekerjasama dengan berbagai pihak seperti :

- Yayasan ELTI sebagai pendamping Pokdarwis Lestari Sungai Hitam

- Pemerintah Kelurahan Kampung Lama dan Pemerintah Kecamatan Samboja

- Politeknik Pertanian Samarinda sebagai narasumber dalam pelaksanaan pelatihan

- BALITEK KSDA Kecamatan Samboja sebagai narasumber dalam pelaksanaan pelatihan

Dengan adanya modal sosial yang dimiliki yaitu berisi jaringan, norma, dan kepercayaan ada disana membuat masyarakat merasa bisa bangkit dari adanya virus covid-19 ini. Solidaritas dan semangat dari masyarakat sekitar akan menjadi satu hal yang sangat penting bagi kehidupan bekantan. Banyak yang belum mengetahui jika modal sosial tidak selalu dikaitkan dengan uang. Berbagi pengetahuan juga merupakan dari modal sosial yang bisa bermanfaat bagi masyarakat.

Pokdarwis Lestari Sungai Hitam merupakan binaan dari PT Pertamina Hulu
Mahakam yang telah diberi fasilitas untuk penyulingan minyak kayu puth sebagai bentuk dukungan untuk membangkitkan perekonomian masyarakat khususnya anggota Pokdarwis.

Tujuan dari pelatihan ini adalah untuk memberikan pengetahuan dan keterampilan yang diperlukan bagi masyarakat lokal sekitar sungai hitam, NGO, pemerintah daerah setempat untuk dapat melakukan rehabilitasi cadangan area hutan mangrove sungai hitam untuk mencapai praktik terbaik untuk rehabilitasi hutan. Selain itu, peserta diharapkan dapat mempraktikkan hasil pelatihan dan melakukan proses pengemasan agar hasilnya dapat dijual secara umum. Dengan demikian masyarakat secara langsung telah mendukung pelestarian bekantan dan habitatnya.

Dengan bantuan alat destilasi yang diberikan Pokdarwis Lestari Sungai Hitam melakukan uji coba pertama yang didampingi oleh ELTI dan Balitek KSDA yang dihadiri oleh pemerintah desa setempat dan diharapkan bisa menghasilkan berbagai produk turunan dari minyak kayu puth sebagai ciri khas ekowisata bekantan sungai hitam.

\section{Kesimpulan}

Penelitian ini bertujuan untuk mengetahui bagaimana kawasan ekowisata bekantan sungai hitam di masa pandemik seperti sekarang ini. Pengelola ekowisata yaitu Pokdarwis Lestari yang kehilangan pekerjaan semenjak adanya pandemik ini sehingga mereka banyak yang menganggur. Maka dari itu dibuatkan pelatihan penyulingan minyak kayu putih karena di tempat ekowisata bekantan banyak terdapat pohon minyak kayu putih 
yang bisa dimanfaatkan. Dengan adanya pelatihan ini diharapkan masyarakat sekitar tidak lagi menebang pohon minyak kayu puth karena bekantan juga biasa bermain di pohon tersebut. Selain itu juga dengan adanya pelatihan ini Pokdarwis Lestari Sungai Hitam bisa memanfaatkan pelatihan dengan sebaik-baiknya sebagai keterampilan yang bisa menghasilkan dengan mengolah daun minyak kayu putih untuk meningkatkan nilai jual dengan menghasilkan berbagai produk turunan dari minyak kayu putih sebagai produk khas di ekowisata bekantan sungai hitam.

\section{Daftar Pustaka}

Atmoko, T. (2010). Strategi Pengembangan Ekowisata Pada Habitat Bekantan (Nasalis Larvatus Wurmb.) Di Kuala Samboja, Kalimantan Timur. Samboja: Balai Penelitian Teknologi Perbenihan Samboja

Budiman, D. (2020). 19 Covid-Pandemi dalam 19 Perspektif. Parepare: IAIN Parepare Nusantara Press

Iskandar, Sofian. dkk. 2017. Status Populasi dan Konservasi Bekantan (Nasalis Larvatus Wurmb. 1787) Di Habitat Rawa Gelam, Kalimantan Selatan. Hutan dan Konservasi Alam, 14 (2): 1-10

Rijanta, R. D. (2018). Modal Sosial Dalam Manajemen Bencana. Yogyakarta: Gadjah Mada University Press.

Setiawan, A. A. (2018). Metodologi Penelitian Kualitatif. Sukabumi: CV Jejak.

Sutopo, H. B. (2002). Metodologi Penelitian Kualitatif (Dasar Teori dan Terapannya dalam Penelitian) Edisi Pertama ed.). Surakarta: Sebelas Maret University Press.
Widiastuti, F., Erianto, Rifanjani, S. (2017). Habitat Bekantan (Nasalis Larvatus Wurmb) Di Dalam dan Sekitar Areal IUPHHK-HT PT. Bina Silva Nusa Kecamatan Batu Ampar Kabupaten Kubu Raya Provinsi Kalimantan Barat. Jurnal Hutan Lestari, 5 (3): 610-617.

William, \& William, H. D. (2020). Social Distancing. USA: An Imprint of Lerner Publishing Group, Inc.

Yudianto. (2017). Peranan Modal Sosial Dalam Pengembangan Kelompok Usaha Kecil (Studi Mengenai Kelompok Batik Tulis Kebon Indah di Desa Kebon, Kecamatan Bayat, Kabupaten Klaten). Yogyakarta: Universitas Gadjah Mada. 